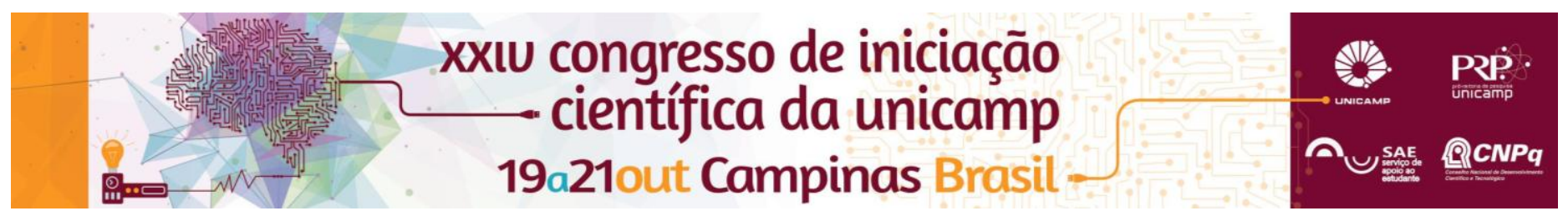

\title{
A devoção e o instinto no corpo: um estudo no eixo Estruturação da Personagem do Método BPI.
}

\section{Larissa S. Turtelli, Yasmin B. Capozzoli*}

\section{Resumo}

Trata-se de uma pesquisa que teve como objetivo dar continuidade às investigações realizadas no projeto de iniciação científica "A dança do orixá lansã: um estudo a partir do eixo Co-habitar com a Fonte do método BPI" (processo FAPESP 2013/12728-9), através do desenvolvimento de uma criação artística no terceiro eixo do método BPI (Bailarino-Pesquisador-Intérprete): A Estruturação da Personagem. Esta pesquisa também estabeleceu uma relação com outras quatro iniciações científicas no mesmo método, chegando a um produto artístico coletivo denominado "Depois Daquele Canto".

\section{Palavras-chave:}

Bailarino-Pesquisador-Intérprete (BPI), Estruturação da Personagem.

\section{Introdução}

Este projeto teve como principal objetivo a imersão da pesquisadora em uma criação artística dentro do eixo Estruturação da Personagem do método BPI. Para tal, foi realizada uma pesquisa de campo junto com outros quatro pesquisadores de iniciação científica no mesmo método focando praticantes do Candomblé da cidade de Cachoeira (BA), chegando a um produto artístico coletivo.

\section{Resultados e Discussão}

A pesquisa foi realizada em duas etapas centrais: a prática, que compreendeu a pesquisa de campo, os Laboratórios Dirigidos e a criação do trabalho artístico e posteriormente a fase de análise de todo o processo. A relação da pesquisa de campo com os laboratórios dirigidos teve como resultado a personagem "Bayá" que se denomina como a mulher "mais velha do mundo" e é responsável por transformar tudo o que morre em vida nova. A análise de todo o processo esclareceu que os conteúdos da personagem "Bayá" começaram a ser elaborados desde os primeiros Laboratórios Dirigidos. Esses conteúdos (imagens, emoções, sensações, corpos e paisagens) eram trazidos aos poucos e com os trabalhos de laboratório foram sendo elaborados até ser possível chegar a uma síntese dos mesmos: a personagem "Bayá".

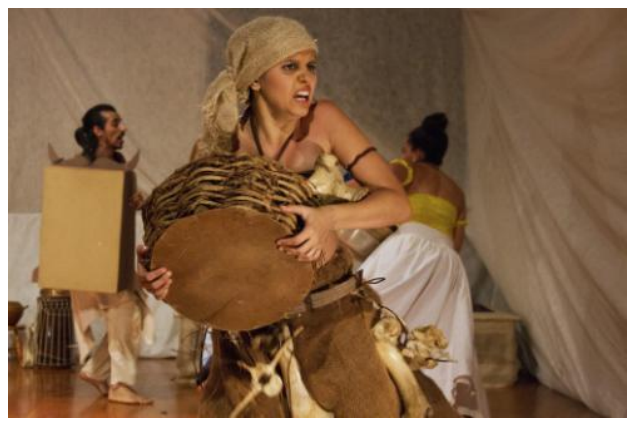

Figura 1. Personagem "Bayá" com cesto em "Depois Daquele Canto" (Fotografia de Marina Pires).

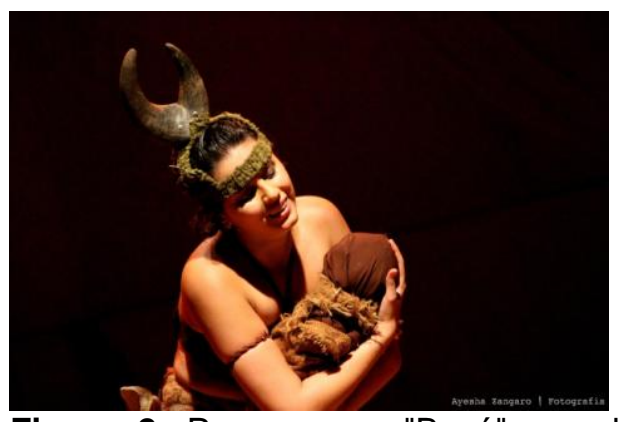

Figura 2. Personagem "Bayá" com bebê em "Depois Daquele Canto" (Fotografia de Ayesha Zangaro).

\section{Conclusões}

Só foi possível compreender o processo do método BPI após vivenciar na prática todas as etapas propostas por ele. A análise de todo o processo resultou em um maior entendimento de que os três eixos propostos, juntamente com as ferramentas do método, resultam na personagem, que é construída desde o começo do trabalho com o método, trazendo conteúdos relacionados tanto à pesquisa de campo, quanto à individualidade corporal da pesquisadora. Pode-se perceber assim o funcionamento sistêmico do método BPI e o processo minuciosos de elaboração dos conteúdos no corpo da pesquisadora.

\section{Agradecimentos}

Ao povo de santo, à Profa. Dra. Graziela Rodrigues, à Profa. Dra. Larissa Turtelli, à Elisa Costa, a todo o Grupo de Pesquisa Bailarino-Pesquisador-Intérprete e Dança do Brasil e ao Departamento de Artes Corporais do IA da Unicamp.

RODRIGUES, G.E.F. O método BPI (Bailarino-Pesquisador-Intérprete) e o desenvolvimento da imagem corporal: reflexões que consideram o discurso de bailarinas que vivenciaram um processo criativo baseado neste método. 2003. Tese (Doutorado em Artes) - Instituto de Artes, Universidade Estadual de Campinas, Campinas, 2003. RODRIGUES, G.E.F. As Ferramentas do BPI (BailarinoPesquisador-Intérprete). In: Anais do I Simpósio e I Congresso Brasileiro de Imagem Corporal (ISBN: 9788599688120). UNICAMP. Campinas, SP. 2010.

TURTELLI, L.S.: O espetáculo cênico no método Bailarino-Pesquisador-Intérprete (BPI): Um estudo a partir da criação e apresentações do espetáculo de dança Valsa do Desassossego. Tese (Doutorado em Artes) Instituto de Artes, Universidade Estadual de Campinas, Campinas, 2009. 